\title{
2006-1643: AN INTERNATIONAL STUDY OF ROBOTICS COURSES IN THE COMPUTER SCIENCE/ENGINEERING CURRICULUM
}

\section{Afsaneh Minaie, Utah Valley State College}

AFSANEH MINAIE is an associate professor in the Computing and Networking Sciences Department at Utah Valley State College. She received a B.S., M.S. and Ph.D. all in Electrical Engineering from University of Oklahoma in 1981, 1984 and 1989 respectively. Her current interests are in Computer Architecture, Embedded Systems, Digital Signal Processing, Digital Design, and Computer Interfacing.

\section{Reza Sanati, Utah Valley State College}

REZA SANATI MEHRIZY is an associate professor of the Computing and Networking Sciences Dept. at Utah Valley State College, Orem, Utah. He received his MS and PhD in Computer Science from University of Oklahoma, Norman, Oklahoma. His research focuses on diverse areas such as: Database Design, Data Structures, Artificial Intelligence, Robotics, and Computer Integrated Manufacturing. 


\title{
An International Study of Robotics Courses in the Computer Science/Engineering Curriculum
}

\begin{abstract}
Robots are great motivation tools for teaching different concepts in engineering as well as computer science. Many courses involve simple robot construction and its programming. Theses robots usually contain a microcontroller, a few sensors, motors, and a body. These courses are excellent vehicles for teaching engineering concepts and they tend to be dominated by hardware concepts. This paper will discuss whether such a course is adequate for computer engineering area of specialization in a computer science department.

In our computer science department, there are four areas of specialization. These four areas of specializations are computer science, software engineering, networking, and computer engineering. In this curriculum, the students matriculate into the CNS department after successfully completing the requirements of 30 hours of core courses common to all computer science students. The students continue taking core courses until the first semester of their junior year, when they begin choosing their electives from different specialization areas.

This paper will address the question of what type of robotics course is adequate for computer engineering area of specialization in a computer science department by doing a national and an international survey of computer science and computer engineering curriculums. The intention is to see if robotics courses are offered and what the contents of those courses are. Also see if there are differences in the course content of a computer science robotics course versus a computer engineering robotics course.
\end{abstract}

\section{Introduction}

Robotics is a well-recognized motivational tool for engineering as well as computer science education. It is an enjoyable topic for many students. Typically, the study of robotics has been limited to graduate level courses at big universities. In the last few years, the advent of smaller, less expensive robots has made it possible for smaller institutions to afford integrating robotics in their undergraduate computer science and engineering curriculum.

Over the years, robots have been used to teach computer science and engineering. Computer science and engineering departments use robots in various ways:

- Using robots in Introductory computer science education

- An Introduction to Robotic Course

- Using Robotics in Artificial Intelligence Course

- Senior Capstone Design Project Course 


\section{Using Robots in the Introductory Computer Science Education}

Interest in the use of robots as an educational tool has boomed within the past few years. The reason is that robotic systems are now affordable, powerful, and reliable to be used in college classrooms. Educators are using robots more across the curriculum ${ }^{1}$. For example, robots were used in a non-major introductory programming course for Educational Technology students ${ }^{2}$. In the computer science departments, robots are used to teach fundamental concepts in

programming $3,4,5,6$. Lopez has introduced a way to teach algorithms through algorithm concretization. Their approach combines algorithm visualization and robotics to make algorithm alive in the real world objects ${ }^{7}$. In a study done by Fagin, he reports that in different sections of an introductory course on programming, worse results were observed in the sections where they were using robots as a teaching tool versus nonrobotics sections ${ }^{8}$. More studies needs to be done on this subject.

\section{An Introduction to Robotic Course}

Usually, this type of course looks at robotics from several angles, i.e., technically, historically, and socially. This course is usually designed for computer science and engineering students. It gives hands-on experiences with robotic technology and provides basic material on the field of robotics. A robotic course takes a hands-on- approach to introducing the basic concepts in robotics, focusing usually on autonomous mobile robots.

\section{Using Robotics in Artificial Intelligence Course}

Because of the availability of low cost, yet powerful robots, using robots in the traditional undergraduate Artificial Intelligent course is an emerging practice. The approach in this type of courses is to use robots to emphasize high-level knowledge-based AI algorithms. Robots serve as the platform for the assignment of the traditional projects ${ }^{9}$. "The modern view of artificial intelligence is that it is the study of intelligent agents - autonomous computing systems that perceive their environments and act upon them in away that both responds to changes in their environment and works toward underlying goals. The intelligent agents metaphor is a way of bringing together the many strands of work carried out under the banner of AI and presenting them to students in a convincing way. For example, thinking of an agent exploring an environment is a natural way to introduce search techniques, and considering how agents must respond to changes in their environments clearly shows the advantage of behavior-based techniques. Robots are prototypical agents that have to move around and react to their environment in pursuit of their goals" ${ }^{10}$. So, it is appropriate to use robotic projects in an AI course.

\section{Senior Capstone Design Project Course}

Usually, in a computer science and engineering curriculum, there is a Senior Design Project course. The senior design experience is intended to be a culminating experience in students' education as a computer engineer or computer scientist. In planning, designing, and executing one's project, students will be expected to bring disparate pieces of knowledge that a student have gained throughout ones studies. An option for these types of courses is to use robotic- 
development projects. "The nature of these robotic-development projects allows a number of additional objectives to be met, beyond those directly related to the application of computer science/engineering fundamentals, including a number of learning objectives specifically required for ABET certified programs" ${ }^{11}$. A few examples are ${ }^{11}$ :

- Ability to design system, components, or process to meet needs.

- Ability to communicate effectively

- Ability to function on multidisciplinary teams

- Ability to use techniques, skills, and modern engineering tools necessary for engineering practice.

An example of this sort of projects is Robot Soccer or Robot Racer where undergraduate students design, build, and program robots that play soccer or race autonomously. These types of projects tend to be both fun and to stretch the students' technical abilities. In these types of projects students are given an opportunity to bring together different aspects of their education.

\section{Background Information}

Utah Valley State College (UVSC) is located at Utah Valley, was founded in 1941. UVSC is a state college comprised of two interdependent divisions. The lower division embraces and preserves the philosophy and mission of a comprehensive community college, while the upper division consists of programs leading to baccalaureate degrees in areas of high community demand and interest ${ }^{1}$. Currently, UVSC offers 13 baccalaureate degrees. UVSC is the fastest growing college in the Utah System of Higher Education with over 23,000 students attending. The Bachelor of Science in Computer Science was one of the first Bachelor of Science programs which was approved in 1992 and implemented in $1993^{12}$.

In addition to the associate degrees, the Computing and Networking Sciences (CNS) department offers a Bachelor's Degree in Computer Science with four areas of specialization which include Computer Science (traditional), Computer Engineering, Software Engineering and Computer Networking. The curriculum content for the Computer Science degree is based on the 2001 ACM Curriculum Report. The CNS department has 11 full time faculties. Half of the faculty has earned a Ph.D. degree and the other half masters degrees. The Computer Science degree at UVSC is accredited by ABET in 2002 and currently has 869 students.

The Bachelor of Science in Computer Science program was one of the first Bachelor of Science programs implemented at UVSC in 1993. The program's goal has been to provide a quality program that meets accreditation standards while providing the students with a skill set that allows them to succeed in computing careers. ${ }^{2}$

Computing Curriculum - Computer Engineering draft $2004^{14}$ specifies eighteen knowledge areas; sixteen of which relates directly to Computer Engineering and two relate to mathematics (probability and statistics, discrete structures). Comparing Computer Engineering area of specialization curriculum at UVSC with the knowledge areas specified in that draft, it can be seen that our curriculum addresses all of the 18 areas specified. 


\section{A Study of Computer Science/Engineering Curriculums}

The motivation for this study was to decide what type of robotics course to add to the curriculum of our Computer Engineering Area of Specialization in the Computer Science Department. To make the decision, we did an international survey of computer science and engineering curriculums which is given in Table 1. The table includes the following:

- The name of the universities

- The country which they are located in

- Whether they have a computer science or computer engineering departments

- Whether a Robotics course is being taught in their computer science/engineering departments.

- Whether a Project Course is being offered in their computer science/engineering departments.

- The last column gives comments on different universities programs

This study shows that only a small percentage of programs in computer science/engineering have a course on Robotics in their undergraduate curriculum. Robotics courses are usually offered as an elective course. Robotic courses are offered more in the computer science curriculum than in the computer engineering curriculums. In the computer engineering departments the trend is more toward Design Project courses where robots are designed. A number of Computer Engineering programs offer a graduate course on Robotics.

\section{A Survey of Books available for Robotic Courses}

- Thrun and Burgard, Probalistic Robotics, MIT Press, 2005, ISBN \# 0-262-20162-3.

- Spong, Hutchinson and Vidyasagar, Robot Modeling and Control, Wiley, 2006, ISBN \# 0-471-64990-2.

- Conrad and Mills, STIQUITO for Beginners: An Introduction to Robotics, Robot Kit Included, Wiley, 1999, ISBN \# 0-8186-7514-4

- Arkin, R., Behavior-Based Robotics, MIT Press, 1998, ISBN\# 0-262-01165-4

- Brooks, R., Cambrian Intelligence: The Early History of the New AI, Bradford Publishing, ISBN\# 0-262052263-2.

- Everett, H., Sensors for Mobile Robots, A.K. Peters, Ltd., ISBN\# 1-56881-048-2

- Latombe, J., Robot Motion Planning, Klumer Academic Publisher, ISBN\# 0-79239206-X

- Murphy, Robin, an Introduction to AI Robotics, MIT Press, 2000, ISBN \# 0-262-133830 .

- Nolfi, Stefano, Evolutionary Robotics, MIT Press, 2000.

- Craig, John, Introduction to Robotics: Mechanics and Control: 3/e, Pearson Education, 2005, ISBN \# 0201543613.

- Rehg, James, Introduction in CIM Systems: 5/e, Pearson Education, 2003, ISBN \# 0130602434.

- Niku, Saeed, Introduction to Robotics, Analysis, Systems, Applications: 1/e, Pearson 
Education, 2002, ISBN \# 0130613096.

- Bra unl, Thomas, Embedded Robotics, Springer, 2003, ISBN \# 3-540-03436-6.

- Choset, Howie, Principles of Robot Motion, MIT Press, 2005, ISBN\# 0-262-03327-5.

- Bekey, George, Autonomous Robots, MIT Press, 2005, ISBN \# 0-262-02578-7.

- Breazeal, Cynthia, Designing Sociable Robots, MIT Press, 2002, ISBN \# 0-262-025108 .

- Nolfi, Stefano and Dario Floeano, Evolutionary Robotics, MIT Press, 2004, ISBN \# 0262-64056-2.

- Siegwart, Ronald and Illah Nourbakhsh, Introduction to Autonomous Mobile Robots, The MIT Press, ISBN \# 0-262-19502.

- $\quad$ Stone, Peter, Layered Learning in Multiagent Systems, MIT Press, 2000, ISBN \# 0-26219438-4.

- Mason, Mattew, Mechanics of Robotic Manipulation, MIT Press, 2001, ISBN \# 0-26213396-2.

- Wooldridge, Michael, Reasoning about Rational Agents, MIT Press, 2000, ISBN \# 0262-23213-8.

- Dorigo, Marco and Marco Colombetti, Robot Shaping, MIT Press, 1997, ISBN \# 0-26204164-2.

- $\quad$ Thurn, Sebastian, Robotics - Science and System I, MIT Press, 2005, ISBN \# 0-26270114-6.

- Ayers, Joseph, Neurotechnology for Biomimetic Robots, MIT Press, 2002, ISBN \# 0262-01193-X.

- Siegwart, Roland and Illah R. Nourbakhsh, Introduction to Autonomous Mobile Robots, MIT Press, 2004, ISBN \# 0-262-19502-X.

- Martin, Fred, Robotic Explorations, Prentice Hall, 2001, ISBN \# 0-13-089568-7.

- Dudek, Gregory and Michael Jenkin, Computational Principles of Mobile Robotics, Cambridge University Press, 2000, ISBN \# 0-521-56876-5.

\section{Summary and Future work}

We have done an international study of Computer Science/Engineering curriculums to decide what type of robotics course to add to the curriculum of our Computer Engineering Area of Specialization in the Computer Science Department. From the study it appears that computer science curriculums in the US offer more Robotics courses than other countries. However, it appears that most of the Computer Engineering programs do not offer Robotics courses. The number of programs in both Computer Science and Engineering offering a project course is more than the ones offering a Robotic course.

After doing this study, we have decided to concentrate on robotic-development projects for our Senior Capstone Design Project course. The reason for this choice is that our Computer Engineering program is an area of specialization in the computer science department. In our curriculum, we do not have space to add a Robotics course. However, we feel that it is important for our students to be exposed to robotics. We feel that concentrating on robotic-development projects will help our students in both theoretical knowledge as well as practical one. The followings are the key learning objectives for a robotic-development project ${ }^{28}$ : 
Complete a design project that requires the use of knowledge and skills acquired during the undergraduate educational experience.

Learn the basic business practices found in most industrial workplaces.

Learn to function as part of a team.

Learn and practice written and oral presentation skills.

Work within a design environment with design constraints similar to real-world projects.

Be better prepared to transition into the workplace or graduate school

In this paper, we have done a partial survey of textbooks available in the area of robotics. A study can be done on the Computer Science/Engineering course contents to see which universities are using robotics as a tool for teaching Computer Science/Engineering courses.

Table 1 - A Survey of Robotic Courses in the CS/CE Programs in Different Countries

\begin{tabular}{|c|c|c|c|c|c|c|}
\hline Universities & Country & $\begin{array}{l}\text { Computer } \\
\text { Science }\end{array}$ & $\begin{array}{l}\text { Computer } \\
\text { Engineering }\end{array}$ & $\begin{array}{l}\text { Robotics } \\
\text { Course }\end{array}$ & $\begin{array}{l}\text { Project } \\
\text { Courses } \\
\text { on } \\
\text { Robotics }\end{array}$ & Comments \\
\hline $\begin{array}{l}\text { Florida State } \\
\text { University }^{37}\end{array}$ & USA & $\mathrm{X}$ & $\mathrm{X}$ & No & No & \\
\hline $\begin{array}{l}\text { Shanghai } \\
\text { University }^{23}\end{array}$ & China & $\mathrm{X}$ & $\mathrm{X}$ & No & No & \\
\hline $\begin{array}{l}\text { Vanderbilt } \\
\text { University }^{24}\end{array}$ & USA & $\mathrm{X}$ & $\mathrm{X}$ & No & No & $\begin{array}{ll}\text { Graduate } & \\
\text { course } & \text { on } \\
\text { Robotics } & \\
\end{array}$ \\
\hline $\begin{array}{l}\text { Michigan } \\
\text { Technological } \\
\text { University }^{22}\end{array}$ & USA & $\mathrm{X}$ & $\mathrm{X}$ & No & No & \\
\hline $\begin{array}{l}\text { Princeton } \\
\text { University }^{21}\end{array}$ & USA & $\mathrm{X}$ & & No & No & \\
\hline 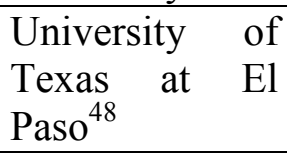 & USA & $\mathrm{X}$ & & No & No & \\
\hline $\begin{array}{l}\text { Embry-Riddle } \\
\text { Aeronautical } \\
\text { University }^{25}\end{array}$ & USA & $\mathrm{X}$ & $\mathrm{X}$ & No & No & \\
\hline $\begin{array}{l}\text { Oregon State } \\
\text { University }^{26}\end{array}$ & USA & $\mathrm{X}$ & & No & Yes & \\
\hline $\begin{array}{l}\text { Ohio State } \\
\text { University }^{27}\end{array}$ & USA & & $\mathrm{X}$ & No & & $\begin{array}{l}\text { Graduate } \\
\text { Course in } \\
\text { Real-Time } \\
\text { Robotics } \\
\text { Systems }\end{array}$ \\
\hline North South & Bangladesh & $\mathrm{X}$ & & No & No & \\
\hline
\end{tabular}




\begin{tabular}{|c|c|c|c|c|c|c|}
\hline \multirow{2}{*}{$\begin{array}{l}\text { University }^{30} \\
\text { North South } \\
\text { University }\end{array}$} & & & & & & \\
\hline & Bangladesh & & $\mathrm{X}$ & Yes & & $\begin{array}{l}\text { Graduate } \\
\text { course in } \\
\text { Robotics }\end{array}$ \\
\hline $\begin{array}{l}\text { University of } \\
\operatorname{Utah}^{39}\end{array}$ & USA & & $\mathrm{X}$ & No & No & $\begin{array}{l}\text { Graduate } \\
\text { Course in } \\
\text { Robotics }\end{array}$ \\
\hline $\begin{array}{l}\text { Northwestern } \\
\text { University }^{34}\end{array}$ & USA & $\mathrm{X}$ & $\mathrm{X}$ & Yes & No & $\begin{array}{l}\text { Behavior } \\
\text { Based } \\
\text { Robotics is a } \\
\text { technical } \\
\text { elective } \\
\text { course }\end{array}$ \\
\hline $\begin{array}{l}\text { University of } \\
\text { Pennsylvania }^{33}\end{array}$ & USA & $\mathrm{X}$ & $\mathrm{X}$ & Yes & No & $\begin{array}{l}\text { Robotics } \\
\text { course is an } \\
\text { elective } \\
\text { course }\end{array}$ \\
\hline $\begin{array}{l}\text { Isfahan } \\
\text { University of } \\
\text { Technology }\end{array}$ & Iran & $\mathrm{X}$ & $\mathrm{X}$ & No & Yes & \\
\hline $\begin{array}{l}\text { Sharif } \\
\text { University of } \\
\text { Technology }\end{array}$ & Iran & & $\mathrm{X}$ & No & Yes & \\
\hline $\begin{array}{l}\text { Fachhochschule } \\
\text { Essligen } \\
\text { Hochschule Fur } \\
\text { Technik }\end{array}$ & Germany & & $\mathrm{X}$ & No & No & \\
\hline $\begin{array}{l}\text { University } \\
\text { Bradford }^{35}\end{array}$ of & England & $\mathrm{X}$ & & No & Yes & \\
\hline $\begin{array}{l}\text { University of } \\
\text { Oxford }^{46}\end{array}$ & England & $\mathrm{X}$ & & No & Yes & \\
\hline $\begin{array}{l}\text { Balliol } \\
\text { College }^{51}\end{array}$ & England & $\mathrm{X}$ & $\mathrm{X}$ & No & Yes & \\
\hline $\begin{array}{l}\text { University of } \\
\text { South Florida }^{47}\end{array}$ & USA & & $X$ & No & Yes & \\
\hline $\begin{array}{l}\text { Angila Ruskin } \\
\text { University }^{36}\end{array}$ & England & $\mathrm{X}$ & & No & No & \\
\hline $\begin{array}{l}\text { Boston } \\
\text { University }^{15}\end{array}$ & USA & & $\mathrm{X}$ & No & No & \\
\hline $\begin{array}{l}\text { Brown } \\
\text { University }^{16}\end{array}$ & USA & $\mathrm{X}$ & & Yes & & $\begin{array}{l}\text { Building } \\
\text { Intelligent } \\
\text { Robots (CS } \\
148) \\
\end{array}$ \\
\hline $\begin{array}{l}\text { Bonaventure } \\
\text { University }^{19}\end{array}$ & USA & $\mathrm{X}$ & & Yes & Yes & $\begin{array}{l}\text { Advanced AI } \\
\text { and Robotics }\end{array}$ \\
\hline
\end{tabular}




\begin{tabular}{|c|c|c|c|c|c|c|}
\hline & & & & & & $\begin{array}{l}\text { Projects (CS } \\
442) . \\
\text { CS } 342 \quad- \\
\text { Robotics \& } \\
\text { Computer } \\
\text { Vision }\end{array}$ \\
\hline $\begin{array}{l}\text { Brigham } \\
\text { Young } \\
\text { University }^{28}\end{array}$ & USA & $\mathrm{X}$ & $\mathrm{X}$ & No & Yes & \\
\hline $\begin{array}{l}\text { University of } \\
\text { Joensuu }^{18}\end{array}$ & Finland & $\mathrm{X}$ & & No & No & $\begin{array}{ll}\text { Use } & \text { of } \\
\text { Robots } & \text { to } \\
\text { teach } & \\
\text { Algorithm } & \\
\end{array}$ \\
\hline $\begin{array}{l}\text { Tokyo Institute } \\
\text { of } \\
\text { Technology }{ }^{17}\end{array}$ & Japan & $\mathrm{X}$ & & No & No & \\
\hline $\begin{array}{l}\text { Swarthmore } \\
\text { College }^{20}\end{array}$ & USA & $\mathrm{X}$ & $X$ & Yes & Yes & $\begin{array}{l}\text { CPSC-082 } \\
\text { Mobile } \\
\text { Robotics }\end{array}$ \\
\hline $\begin{array}{l}\text { University } \\
\text { Hanover }\end{array}$ & Germany & $\mathrm{X}$ & & Yes & No & \\
\hline $\begin{array}{l}\text { Stanford } \\
\text { University }^{50}\end{array}$ & USA & $\mathrm{X}$ & & Yes & No & $\begin{array}{l}\text { CS225B } \\
\text { Robot } \\
\text { Programming } \\
\text { Lab }\end{array}$ \\
\hline $\begin{array}{l}\text { California } \\
\text { Institute of } \\
\text { Technology } 42\end{array}$ & USA & $\mathrm{X}$ & & Yes & & $\begin{array}{ll}\text { CS 132 - } \\
\text { Advanced } \\
\text { Robotics }\end{array}$ \\
\hline $\begin{array}{l}\text { Carnegie } \\
\text { Mellon } \\
\text { University }{ }^{43}\end{array}$ & USA & $\mathrm{X}$ & $\mathrm{X}$ & Yes & Yes & $\begin{array}{l}\text { CE: Elective } \\
\text { course on } \\
\text { Robotics }\end{array}$ \\
\hline $\begin{array}{l}\text { California State } \\
\text { Polytechnic } \\
\text { University, } \\
\text { Pomona }\end{array}$ & USA & $\mathrm{X}$ & $\mathrm{X}$ & Yes & No & $\begin{array}{l}\text { CE: ECE } \\
\text { 404- } \\
\text { Robotics } \quad- \\
\text { Technical } \\
\text { Elective }\end{array}$ \\
\hline $\begin{array}{l}\text { Israel Institute } \\
\text { of } \\
\text { Technology } 45\end{array}$ & Israel & $\mathrm{X}$ & & Yes & & $\begin{array}{l}\text { Introduction } \\
\text { to Robotics }\end{array}$ \\
\hline $\begin{array}{l}\text { Massachusetts } \\
\text { Institute of } \\
\text { Technology }\end{array}$ & USA & $\mathrm{X}$ & & Yes & & $\begin{array}{l}\text { Autonomous } \\
\text { Robot } \\
\text { Design } \\
\text { Competition } \\
\end{array}$ \\
\hline
\end{tabular}




\section{References:}

[1] O’Hara, Keith, Investigating Open Source Software, Consortium for Computing Sciences in Colleges, 2002.

[2] Patternson-McNeil, H. and Binkerd, C.L., Resources for Using LEGO ® MindStorms. In Proceedings of the Twelfth Annual CCSC South Central Conference, 2001.

[3] Flowers, T., Teaching Problem Solving, computing, and Information Technology with Robots, CCSC: Northeastern Conference, 2002.

[4] Fagin, Barry, Teaching Computer Science with Robotics Using Ada/Mindstorms 2.0. Proceedings of SIGAda 2001.

[5] Fagin, Barry, Using Ada-Based Robotics to Teach Computer Science. Proceedings of the $5^{\text {th }}$ Annual Conference on Innovation and Technology in Computer Science Education, July 2000 .

[6] Hood, C., Teaching Programming and Language Concepts using LEGOs, ITiCSE 2005.

[7] Lopez, Javier, Sorting out Sorting through Concretization with Robotics, AVI 2004, May 2528 , Italy.

[8] Fagin, Barry and Laurence Merkle, Quantitative Analysis of the Effects of Robots on Introductory Computer Science Education, ACM Journal of Educational Resources in Computing, Vol. 2, No. 4, December 2002.

[9] Kumar, A., Innovation in Undergraduate Computer Science Education, CCSC: Northeastern Conference, 2005.

[10] Sklar, E. and Simon Parsons, Using RoboCup in University-Level Computer Science Education, ACM Journal on Educational Resources in Computing, Vol 4, No.2, June 2004.

[11] Kitts, C. and Neil Quinn, An Interdisciplinary Field Robotics Program for Undergraduate Computer Science and Engineering Education, ACM Journal on Educational Resources in Computing, Vol. 4, No. 2, June 2004.

[12] UVSC - Department of Computing and Networking Sciences, http://www.uvsc.edu , access on December 2003.

[13] Computer Science Program Self Study for the 2002-2003 ABET Accreditation Cycle, Computing and Networking Sciences Department, Utah Valley State College, 2002.

[14] Computing Curricula - Computer Engineering Report (Ironman Draft), http://www.eng.auburn.edu/ece/ccce, access on March 2004.

[15] Boston University, www.bu.edu, access on Dec. 2005.

[16] Brown University, www.cs.brown.edu, access on Jan. 2006.

[17] Tokyo Institute of Technology, www.eng.titech.ac.jp, access on Jan. 2006.

[18] University of Joensuu, www.joensuu.fi, access on Jan. 2006. 
[19] St. Bonaventure University, www.sbu.edu/go/academics, access on Dec. 2005.

[20] Swarthmore College, www.cs.swarthmore.edu, access on Jan 2006.

[21] Princeton University, www.cs.princeton.edu/academics, access on Jan. 2006.

[22] Michigan Tech University, www.ece.mtu.edu/pages/academics, access on Jan 2006.

[23] Shanghai University, www.shu.edu.cn/en, access on Jan. 2006.

[24] Vanderbilt University, www.eecs.uvsc.vanderbilt.edu, access on Jan 2006.

[25] Embry-Riddle Aeronautical University, www.erau.edu/pr/degrees, access on Jan 2006.

[26] Oregon State University, www.eecs.oregonstate.edu, access on Jan. 2006.

[27] Ohio State University, www.ece.osu.edu/academics, access on Dec. 2005.

[28] Brigham Young University, www.byu.edu, access on Jan.2006.

[29] Oregon State University, www.engr.oregonstate.edu, access on Dec. 2005.

[30] North South University, www.northsouth.edu/html/dcse.html, access on Dec. 2005

[31] Massachusetts Institute of Technology, www.mit.edu, access on Jan. 2006.

[32] Isfahan University Technology, www.iut.ac.ir, access on Dec. 2005.

[33] University of Pennsylvania, www.cis.upenn.edu, access on Dec. 2005.

[34] Northwestern University, www.cs.northwestern.edu , access on Jan. 2006.

[35] University of Bradford, www.brad.ac.uk, access on Dec. 2005.

[36] Anglia Ruskin University, www.anglia.ac.uk, access on Jan 2006.

[37] Florida State University, www.cs.fsu.edu, access on Dec. 2005.

[38] Drexel University, www.drexel.edu, access on Jan 2006.

[39] University of Utah, www.cs.utah.edu, access on Jan. 2006.

[40] Sharif University of Technology, http://sharif.ir/ ceinfo/undergraduateCourses.htm, access on Jan. 2006.

[41] Balliol College, www.balliol.ox.ac.uk, access on Jan. 2006.

[42] California Institute of Technology, www.cs.caltech.edu , access on Feb. 2006.

[43] Carnegie Mellon University, www.ece.cmu.edu , access on Feb. 2006.

[44] California State Polytechnic University, Pomona, www.csupomona.edu , access on Feb 2006.

[45] Israel Institute of Technology, www.cs.technion.ac.il, access on March 2006.

[46] University of Oxford, www.ox.ac.uk, access on Feb. 2006. 
[47] University of South Florida, www.usf.edu, access on Feb 2006.

[48] University of Texas at El Paso, www.utep.edu, access on Feb 2006.

[49] University of Hannover, www.uni-hannover.de, access on Feb 2006.

[50] Stanford University, www.stanford.edu, access on March 2006.

[51] Balliol College, www.balliol.ox.ac.uk, access on Feb. 2006. 